Environment Conservation Journal 15(1 \& 2)83-87, 2014

ISSN 0972-3099 (Print) 2278-5124 (Online)

Abstracted and Indexed

\title{
Concentrations of Benzene, Toluene and Xylene (BTX) in Ambient air of Rohtak city, India
}

\author{
Poonam Dalal $^{1}$, Vinay Malik ${ }^{1}$, Dhruva Chaudhry ${ }^{2}$ and Vineeta Shukla ${ }^{1} \bowtie$ \\ Received: 6.09.2013 Revised: 21.12.2013 Accepted: 16.01.2014
}

\begin{abstract}
Environmental monitoring of a particular locality is very important because it has become a serious threat to human beings.The levels of benzene, toluene and xylene of Rohtak (one of the districts of Haryana) were monitored by Passive sampling method. The air samples collected from six different sites using thermal desorption tube were analyzed by Gas Chromatography (GC) with flame ionization detector (FID). Among all the selected sites, levels of benzene were found maximum at petrol pump as compared to the residential site, traffic intersection and industrial area. During winter season the BTX level was higher (Benzene: 4.3, 16.5, 12.2, 7.6, 22.3 and $15.6 \mu \mathrm{g} / \mathrm{m}^{3}$, Toluene: 16.3, 56.2, 30.9, 40.8, 55.5 and $50.2 \mu \mathrm{g} / \mathrm{m}^{3}$, Xylene: $6.3,9.6,8.5,8.9,9.2$ and $8.4 \mu \mathrm{g} / \mathrm{m}^{3}$ ) as compared to summer (Benzene: $4.0,12.6,8.5,8.8,12.3$ and 10.8 $\mu \mathrm{g} / \mathrm{m}^{3}$, Toluene: $38.2,53.1,39.8,42.6,49.6$ and $47.2 \mu \mathrm{g} / \mathrm{m}^{3}$ xylene: $2.3,8.4,6.8,8.0,7.5$ and $5.4 \mu \mathrm{g} / \mathrm{m}^{3}$ ) and $\mathrm{monsoon}$ (Benzene: 2.3, 7.2, 5.6, 6.0, 7.0 and $7.4 \mu \mathrm{g} / \mathrm{m}^{3}$, Toluene: 5.0, 24.0, 14.5, 16.3, 24.8 and $24.6 \mu \mathrm{g} / \mathrm{m} 3, \mathrm{Xylene:} \mathrm{1.8,} \mathrm{6.6,} \mathrm{4.2,} \mathrm{6.3,}$ 6.6 and $\left.6.4 \mu \mathrm{g} / \mathrm{m}^{3}\right)$ seasons among all the sites. The levels of toluene were observed three times higher $\left(50.2 \mu \mathrm{g} / \mathrm{m}^{3}\right)$ than the benzene $\left(15.6 \mathrm{\mu g} / \mathrm{m}^{3}\right)$. The benzene level at petrol pump, industrial area and traffic intersection were observed higher than the standard values.
\end{abstract}

Keywords: Benzene; Passive sampling method, Toluene, Xylene

\section{Introduction}

Benzene, toluene and xylene get concentrated in air due to emissions from burning coal and oil, gasoline service stations, and motor vehicle exhaust (Saxena and Ghosh, 2012). Acute (short-term) inhalation of benzene by human beings may cause drowsiness, dizziness, headache, as well as eye, skin and respiratory tract irritation and at high levels it can even cause unconsciousness (Saxena and Ghosh, 2012). Chronic (long-term) inhalation can cause various disorders in the blood, including reduced numbers of red blood cells and aplastic anemia, in occupational settings (Saxena and Ghosh, 2012). Benzene, toluene and xylene compounds are very harmful pollutants among volatile organic compounds (VOCs) and have been subjected to significant investigations in western countries as well as in India (Tyagi et al., 1999; Tyagi, 2004; Saxena and Ghosh, 2012). Benzene is a significant component of hydrocarbon fraction due to its refractory nature in the combustion process. VOCs comprise a major group of air pollutants which play a critical role in atmospheric Author's Address

${ }^{1}$ Deptt.of Zoology, Maharshi Dayanand University, Rohtak

${ }^{2}$ Deptt. of Medicine and critical care, Pt. B.D.S. University of Health Sciences, Rohtak, India

Email: poonamdalalhooda@gmail.com chemistry (Srivastava et al., 2000). Benzene, toluene and xylene are present in both exhaust and evaporative emission from vehicles and fuel delivery outlets in urban atmosphere. Benzene is a known carcinogen (Schnatter et al., 2005; Esplugues et al., 2010) and haematoxic agent (Lan et al., 2004). There are evidences that air quality is worsening in the developing countries. Like many other cities of India, the ambient air quality of Rohtak is also being deteriorated. Rohtak, a city located $70 \mathrm{~km}$ away from Delhi (Capital of India) towards west has an area of 441100 ha. Being very near to a metropolitan city, it may be one of the reasons for faster urbanization which in turn led to tremendous increase in the number of vehicles in the city. Air pollution at Rohtak city is increasing day by day due to vehicular exhausts. There is no data available which could guide us to plan something in response to the air pollution. We have attempted a study on occurrence of BTX in the Rohtak city of Haryana.

\section{Material and methods}

Study sites

To study the ambient air quality, six sampling sites were selected in the city on the basis of vehicular density and population (Fig. 1). 
Fig. 1. Map of Rohtak city showing selected sites

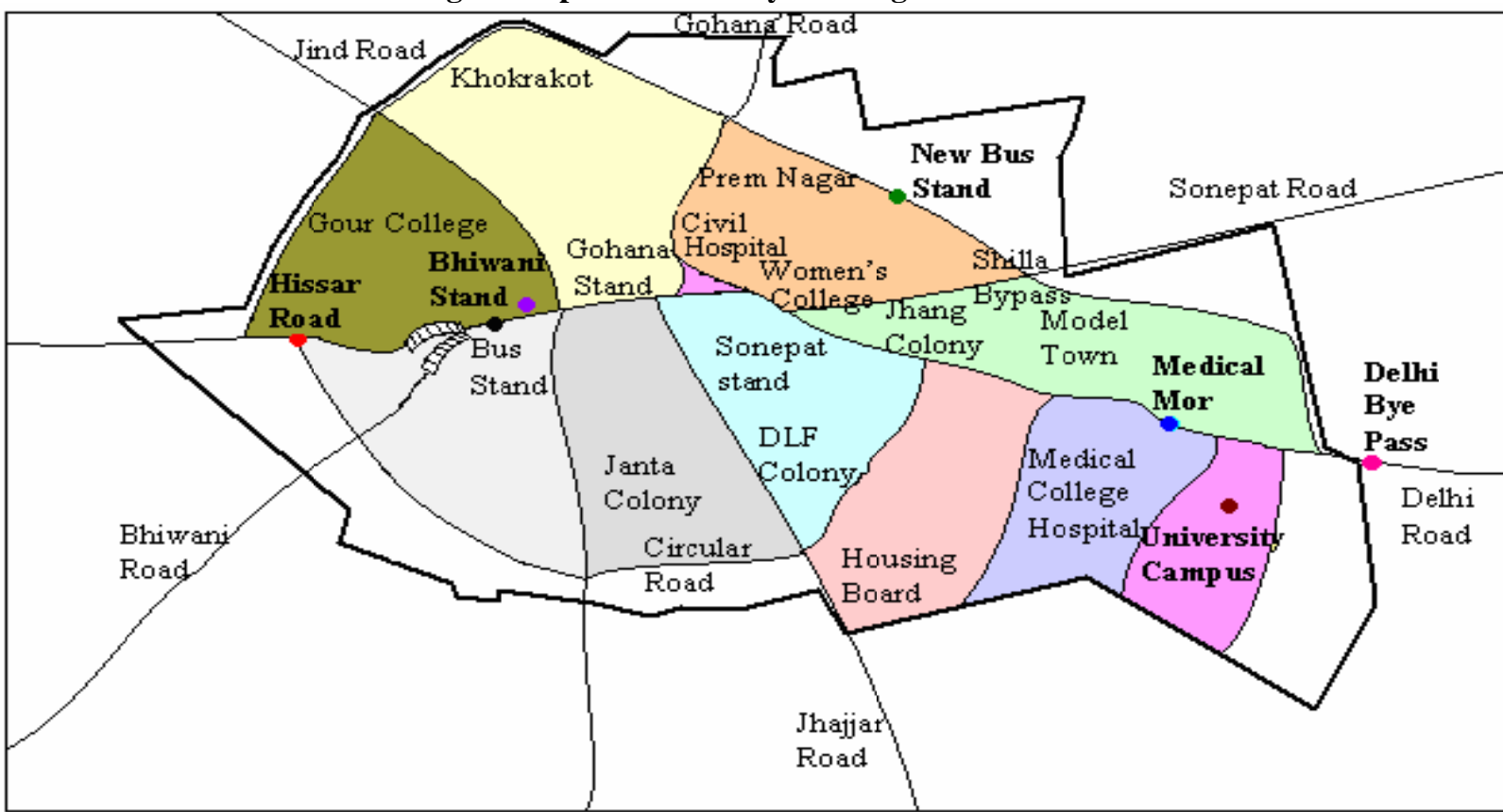

Map of Rohtak city showing selected sites

- Hissar Road

- Bhiwani stand

Major Road

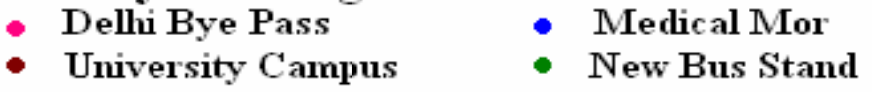

Municipal Boundary
Six charcoal tubes were exposed at each site per season winter (November, December, 2007 and January, 2008), summer (April, May and June, 2008) and monsoon (July, August and September, 2008) seasons. The general features of the selected sites were as follows:

1. University campus- low traffic density, residential site.

2. Delhi bye pass (petrol pump) - High traffic density.

3. Medical mor - City centre, moderate traffic

4. New bus stand - Moderate traffic density having light and heavy vehicles.

5. Bhiwani stand (traffic intersection) - High traffic density

6. Hissar road- Industrial area with high traffic density

\section{Passive Sampling}

An activated charcoal tube was used to detect the benzene, toluene and xylene in ambient air. A diffusion sampling system comprises a sampling layer and a diffusion path in front of this layer. The tube was exposed to ambient air. During this exposure time, the analyses streamed into the activated charcoal due to the concentration gradient between the air and the desorption layer and are absorbed by the charcoal (Berite, 1983). The samples were then collected, and the tubes were taken to the laboratory, where BTX adsorbed on the exposed activated charcoal were extracted in $10 \mathrm{ml}$ $\mathrm{CS}_{2}$ in the desorption bulb by agitating for $30 \mathrm{~min}$ in ultrasonicator. The extracts were filtered through a glass fibre filter and were analyzed using capillary gas chromatography equipped with flame ionization detector.

\section{Results and Discussion}

The mean value of Benzene at University campus, Hissar road, Medical mor, New bus stand, Delhi bye pass and Bhiwani stand was 4.3, 16.5, 12.2, 7.6, 22.3 and $15.6 \mu \mathrm{g} / \mathrm{m}^{3}$ in winter; 4.0, 12.6, 8.5, 8.8, 12.3 and $10.8 \mu \mathrm{g} / \mathrm{m}^{3}$ in summer and 2.3, 7.2, 5.6, 6.0, 7.0 and $7.4 \mu \mathrm{g} / \mathrm{m}^{3}$ in monsoon seasons, respectively (Fig. 2). The mean concentration of benzene was found more than the permissible limit 
$\left(16 \mu \mathrm{g} / \mathrm{m}^{3}\right)$ of National Ambient Air Quality Standard (NAAQS, 2009) at Hissar road and Delhi bye pass in winter season. The concentration of benzene was high at Delhi bye pass in winter season and the minimum concentration was found at University campus in monsoon season.

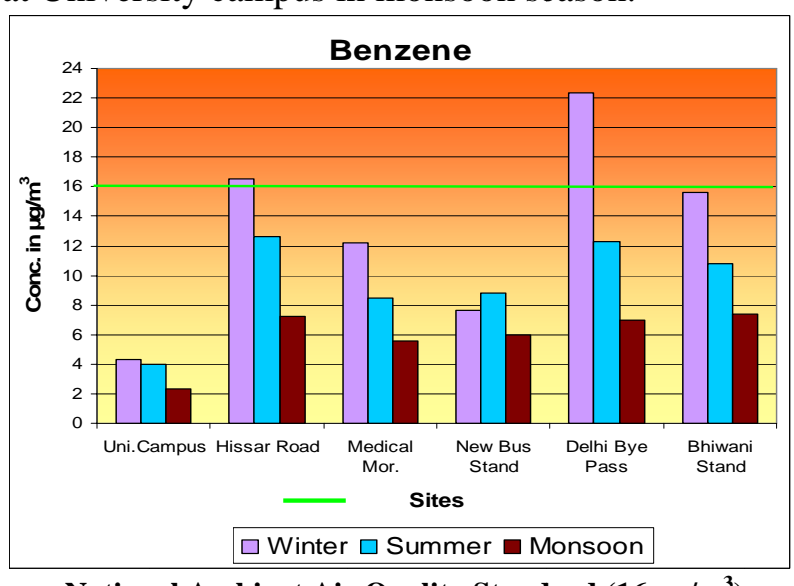

National Ambient Air Quality Standard (16 $\left.\mu \mathrm{g} / \mathrm{m}^{3}\right)$

Fig. 2 Benzene variations from National Ambient Air Quality Standard (Rohtak)

The mean value of Toluene at University campus, Hissar road, Medical mor, New bus stand, Delhi bye pass and Bhiwani stand was 16.3, 56.2, 30.9, 40.8, 55.5 and $50.2 \mu \mathrm{g} / \mathrm{m}^{3}$ during winter; 38.2, 53.1, 39.8, 42.6, 49.6 and $47.2 \mu \mathrm{g} / \mathrm{m}^{3}$ during summer and 5.0, 24.0, 14.5, 16.3, 24.8 and $24.6 \mu \mathrm{g} / \mathrm{m}^{3}$ during monsoon seasons, respectively (Fig 3 ).

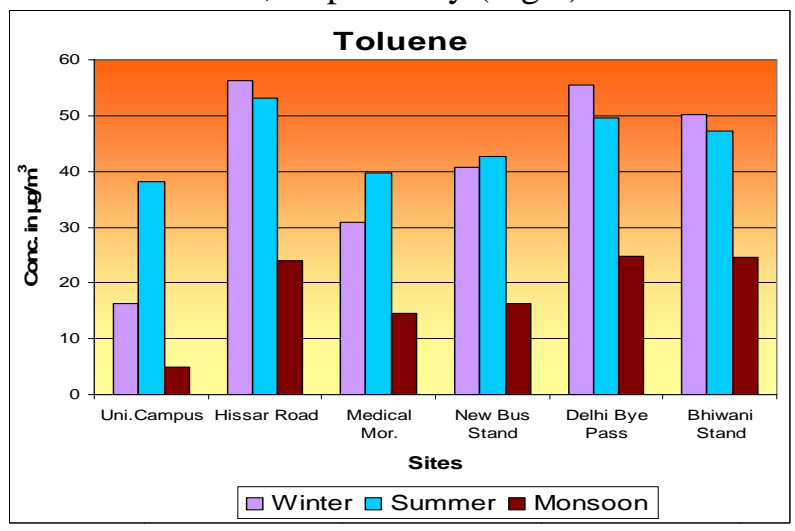

Fig. 3 Concentration of Toluene at different sites of Rohtak City

The maximum concentration of toluene was found at Hissar road in winter season while it was minimum at University campus during monsoon season.The mean value of Xylene at University campus, Hissar road, Medical mor, New bus stand, Delhi bye pass and Bhiwani stand was 6.3, 9.6, 8.5,
8.9, 9.2 and $8.4 \mu \mathrm{g} / \mathrm{m}^{3}$ in winter; 2.3, 8.4, 6.8, 8.0, 7.5 and $5.4 \mu \mathrm{g} / \mathrm{m}^{3}$ in summer and 1.8, 6.6, 4.2, 6.3, 6.6 and $6.4 \mu \mathrm{g} / \mathrm{m}^{3}$ in monsoon seasons, respectively (Fig 4). The maximum concentration of xylene was observed at Hissar road in winter season and minimum concentration was found at University campus in monsoon season. Similarly, mixing ratio of BTEX (benzene, toluene, ethyl benzene xylene ) were measured for the first time in ambient air of Firozabad, Uttar Pradesh, India at five sites (residential, industrial, commercial, refueling pump station and traffic intersection) from March to June 2009. The significant difference observed between the five sites for the residential, industrial, commercial, refueling pump station and traffic intersection areas implies that the five areas have different emission sources. Villanueva et al. (2013) reported the presence of volatile organic compound (VOC) concentrations, including aldehydes, in the coastal, industrial area of Huelva near the Doñana National Park (south-west of the Iberian Peninsula) during July-September 2008 and FebruaryNovember 2009. Kerchich and Kerbachi (2012) studied the levels of air pollution by aromatic organic compounds BTEX in the city of Algiers in area including roadside, tunnel, urban background, and semirural sites. The results indicated that average benzene concentrations in the roadside and inside vehicle exceed largely the limit value. On the other hand, it has been noticed that the concentration levels of other BTEX are relatively high. This study shows that road traffic remains the main source of many local emission in Algiers. Concentration of Benzene, Toluene and Xylene (BTX) in ambient air was measured near seven traffic junctions in the city of Nagpur by Deole et al. (2004). Air samples were collected using organic vapour sampler and analyzed by Gas Chromatograph equipped FID. Benzene concentration was found to be in the range 9.3 to $28.7 \mathrm{microg} / \mathrm{m}^{3}$, Toluene 3.26 to $21.0 \mathrm{microg} / \mathrm{m}^{3}$ and Xylene 4.9 to $15.0 \mathrm{microg} / \mathrm{m}^{3}$. These values are lower than those found in Metropolitan cities like Mumbai. In the above study, the mean concentrations of BTX pollutants were observed maximum in winter season as compared to summer and monsoon season. During winter season there was increased atmospheric stability, which in turn allows for less general circulation and thus, more stagnant air masses. 


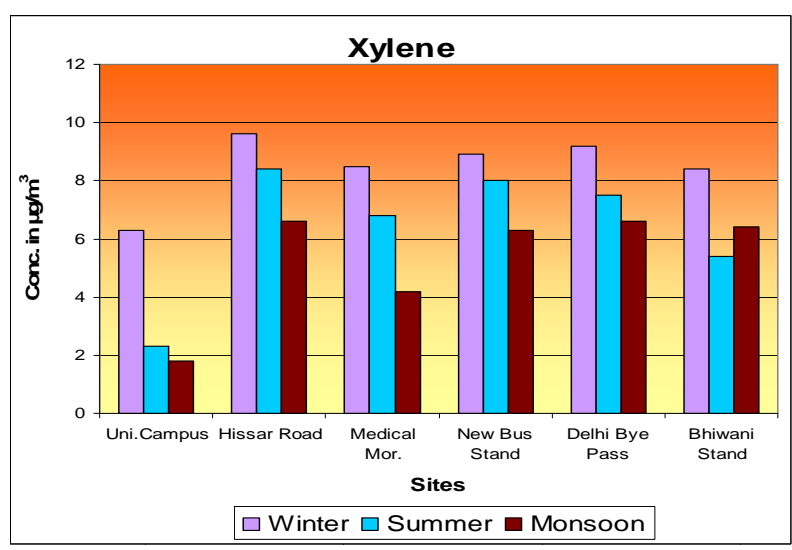

Fig. 4 Concentration of Xylene at different sites of Rohtak City

It prevents an upward movement of air, hence atmospheric mixing is retarded and pollutants are trapped near the ground. Secondly, cold starts in winter lead to longer period of incomplete combustion and longer warm up times for catalytic converter, which generate more pollution. Benzene, toluene and xylene, the most widely used aromatic hydrocarbons, are very useful chemicals, however they are also extremely hazardous as well. There is a link between exposures and adverse health outcomes. The major causes of increased emission of pollutants in urban area include the use of poor quality fuel, traffic congestion and badly maintained motor vehicles. Impact of vehicular pollution on human health in urban areas is at peak level as vehicle emissions are near the ground level where people live and work. The mean level of pollutants was found maximum at Hissar road and minimum at University campus. During the study period, the two sites were selected as maximum (Hissar road) and minimum (University campus) polluted sites. The study site, Hissar road is an industrial area having lots of workshops with heavy traffic density and frequent traffic jams, resulting in building up of air pollutants in that area. This ultimately leads to more exposure to people residing and working in that area. On the other hand the site University campus is clean open area with lots of greenery and also less traffic density and consequently less exposure to its inhabitants. The monsoon results in large amount of precipitation and increased humidity, while rain became responsible for the 'washing off' of ambient air pollutants. Therefore, pollution level was found at minimum level in this season during our study at all the selected sites. Similarly Saxena and Ghosh (2012) reported that the concentration of BTEX was high in commercial sectors of Delhi because of large office complexes and big shopping malls traffic volume was increased and therefore, that becomes a good source for BTEX. Moreover, the main source of BTEX was found to be gasoline exhaust from vehicular fleet and areas with heavy crowd. The concentration of BTEX was highest during winter season followed by monsoon and then in summer. Gasoline or petrol is a petroleumderived liquid mixture consisting mostly of aliphatic hydrocarbons, enhanced with iso-octane or the aromatic hydrocarbons toluene and benzene to increase its octane rating, and is primarily used as fuel in internal combustion engines. Benzene can evaporate from gasoline strongly (Squillace et al., 1997). Furthermore, benzene, toluene and xylene can mainly emit from automobiles due to incomplete combustion of fuel (Saxena and Ghosh, 2012). The high BTX contaminated areas might be the areas associated with gasoline such as gas stations, garages, gasoline storehouses, and traffic area. The human exposure to BTX in air occurs in the gas station, especially at pump-island zone, and traffic areas. The BTX emission occurred during refueling in gas stations are more dominant than in traffic area occurred from unburned fuel in automobile. BTX are toxicant. Especially, benzene is a strong carcinogen. These compounds mean serious risks for public and occupational health and for biological and physical environments (Bruinen et al., 2008). The study suggested that the mean concentration of benzene was found more than the permissible limit $\left(16 \mu \mathrm{g} / \mathrm{m}^{3}\right)$ at Hissar road and Delhi bye pass in winter season. The reason for finding higher concentration of benzene in air may be that it is a component of gasoline. It is a major source of exposure for the subjects from vehicle exhausts and benzene is mostly produced by chemical reactions occurring during combustion of petrol in the engines. Toluene and xylene are also present in most sources along with benzene. Therefore, the concentration of toluene and xylene were increasing with Benzene. Benzene was found maximum at Delhi bye pass $\left(22.3 \mu \mathrm{g} / \mathrm{m}^{3}\right)$ in winter season and minimum at University campus $\left(2.3 \mu \mathrm{g} / \mathrm{m}^{3}\right)$ in monsoon season. Toluene was found maximum at Hissar road $\left(56.2 \mu \mathrm{g} / \mathrm{m}^{3}\right)$ in winter season and minimum at University campus $\left(5.0 \mu \mathrm{g} / \mathrm{m}^{3}\right)$ in monsoon season. Xylene was found 
maximum at Hissar road $\left(9.6 \mu \mathrm{g} / \mathrm{m}^{3}\right)$ in winter season and minimum at University campus $\left(1.8 \mu \mathrm{g} / \mathrm{m}^{3}\right)$ in monsoon season. This work will contribute to the analysis of real emissions of BTX in Rohtak city, for the development of management and for assessment of population exposure variation depending on the location in the city.

\section{Conclusions}

In the present study, ambient air quality of Rohtak city was observed at six different sites (Hissar road, Bhiwani stand, new bus stand, Medical Mor, University campus and Delhi bye pass). The mean concentration of benzene was found more than the permissible limit of National Ambient air Quality Standard $\left(16 \mu \mathrm{g} / \mathrm{m}^{3}\right)$ at Hissar road and Delhi bye pass in winter season. The BTX emission occurred during refueling in filling stations are more dominant than in traffic area occurred from unburned fuel in automobile. Benzene, toluene and xylene compounds are very harmful pollutants among volatile organic compounds (VOCs).

\section{Acknowledgement}

The authors extend their heartfelt feelings of gratitude to Mr. Gurnam Singh (Head, Air pollution Board); Dr. S.K. Tyagi (Senior Scientist) and all the members of Ministry of pollution Board for their advice and help during the course of this investigation.

\section{References}

Berite, M.W., 1983. Measurements of Benzene, Toluene and Xylene in urban area. Atmospheric Environment, 17: 1713-1722.

Bruinen de Bruin, Y., Koistinen, K., Kephalopoulos, S., Geiss, O., Tirendi, S. and Kotzias, D., 2008. Characterisation of urban inhalation exposures to benzene, formaldehyde and acetaldehyde in the European Union: comparison of measured and modelled exposure data. Environmental science and pollution research international 15(5): 417430.

Deole, S., Phadke, K.M. and Kumar, A. 2004. Benzene, toluene and xylene (BTX) pollution in ambient air: a case study. Journal of Environmental Science and Engineering, 46(1): 15-20.

Esplugues, A., Ballester, F., Estarlich, M., Llop, S., FuentesLeonarte, V., Mantilla, E. and Iniguez, C., 2010. Indoor and outdoor air concentrations of BTEX and determinantsin a cohort of one-year old children in Valencia, Spain. Science of the Total Environment, 409(1): 63-69.
Kerchich, Y. and Kerbachi, R., 2012. Measurement of BTEX (benzene, toluene, ethybenzene, and xylene) levels at urban and semirural areas of Algiers City using passive air samplers. Journal of the Air and Waste Management Association, 62(12): 1370-1379.

Lan, Q., Zhang, L.G., Lan, Q., Zhang, L., Li, G., Vermeulen, R., Weinberg, R.S., Dosemeci, M., Rappaport, S.M., Shen, M., Alter, B.P., Wu, Y., Kopp, W., Waidyanatha, S., Rabkin, C., Guo, W., Chanock, S., Hayes, R.B., Linet, M., Kim, S., Yin, S., Rothman, N., Smith, M.T., 2004. Hematotoxicity in workers exposed to low levels of benzene. Science, 306: 1774-1776.

National ambient air quality standards. 2009. CPCB Delhi

Saxena, P. and Ghosh, C., 2012. A review of assessment of benzene, toluene, ethylbenzene and xylene (BTEX) concentration in urban atmosphere of Delhi. International Journal of the Physical Sciences, 7(6): 850 - 860.

Schnatter, A.R., Rosamilia, K. and Wojcik, N.C., 2005. Review of the literature on benzene exposure and leukemia subtypes. Chemico-Biological Interactions, 153-154: 921.

Squillace, P.J., Pankow, J.F., Korte, N.E., and Zogorski, J.S., 1997. Review of the environmental behaviour and fate of methyl tert-butyl ether. Environmental Toxicology and Chemistry, 16: 1836-1844.

Srivastava, P.K., Pandit, G.G., Sharma, S. and Rao, A.M., 2000. Volatile organic compounds in indoor environments in Mumbai, India. The Science of the Total Environment. 225(1-3): 161-168.

Tyagi, S.K., 2004. BTX profile of fugitive emissions \& ambient air at Panipat oil refinery. Indian Journal of Air Pollution Control, 4 (1): 51-60.

Tyagi, S.K., Kamyotra, J.S., Makhijani, S.D., Sengupta, B. and Henschel, P., 1999. Benzene monitoring in urban environment, "Proceedings of New millennium Conference on Retrospect of Indian Research on Environmental Pollution": Focus 21st century, Environmental Monitoring Training and Research Centre( EMTRAC), Central Pollution Control Board (CPCB) \& National Research Development Corporation(NRDC), New Delhi, pp: 15.

Villanueva, F., Notario, A., Adame, J.A., Millán, M.C., Mabilia, R. and Albaladejo, J., 2013. A preliminary study on ambient levels of carbonyls, benzene, toluene and xylene in the south-west of the Iberian Peninsula (Huelva coast), Spain. Environmental Technology, 34(1-4): 289299. 